\title{
Myrtia, ${ }^{\circ} 36$ (2021), 132-142
}

El mito troyano de Memnón y el coloso que canta: variantes del relato en Filóstrato [The Trojan Myth of Memnon and the Singing Colossus: Variants of the Story in Philostratus]

\section{Ivana Selene Chialva}

Universidad Nacional del Litoral*

\begin{abstract}
Resumen:
En el corpus filostrateo se reitera el mito troyano del héroe Memnón con variantes y reformulaciones en diferentes obras: Imágenes, Vida de Apolonio de Tiana y Heroico. La inclusión de relatos míticos ha sido considerada, frecuentemente, como un recurso repetitivo heredero de formas escolares y del gusto arcaizante y libresco de los pepaideuménoi. Este artículo propone un análisis trasversal de las referencias a Memnón en el corpus para demostrar cómo las variaciones al relato mítico son re-escrituras funcionales a una sophía helénica según el programa narrativo del sofista en cada obra.
\end{abstract}

Abstract: $\quad$ The Trojan myth of the hero Memnon is reiterated with variants and reformulations in different works of the Philostratean corpus: Images, Life of Apollonius of Tyana and Heroicus. The inclusion of mythical narrative has been often considered as a repetitive resource inheriting school forms and the archaic and bookish taste of the pepaideumenoi. This article proposes a transversal analysis of alluding to Memnon in the corpus to demonstrate that the variations of the mythical story are functional rewritings of a Hellenic sophia according to the sophist's narrative program in each work.

Palabras clave: $\quad$ relato, Filóstrato, Memnón, escritura, oralidad

Keywords: $\quad$ narrative, Philostratus, Memnon, literacy, orality

Recepción:

$03 / 10 / 2020$

Aceptación:

$06 / 03 / 2021$

Si se considera el total de obras atribuidas al sofista Filóstrato (Vidas de sofistas, Imágenes, Cartas, Gimnástico, Vida de Apolonio de Tiana y Heroico) se advierten dos rasgos principales: desde una mirada de conjunto, el abanico diverso de géneros y temáticas que conforman un corpus proteico (Elsner, 2009); y desde una mirada más focalizada, cómo cada obra comprende en sí misma un compendio de formas retóricas enlazadas o yuxtapuestas en una estructura narrativa compleja (Mestre 2007, 2020). En esa conformación diversa persisten, no obstante, rasgos comunes que permiten trazar claros puntos de contacto en la cartografía cambiante: uno de ellos es la pervivencia de la antigua sophía griega.

En efecto, al leer el corpus se percibe la recurrencia de frases, recursos narrativos o anécdotas ubicados en diferentes circunstancias y vinculados a temas sin aparentemente conexión entre sí: como si, de pronto, el sofista prestidigitador de palabras sacara de la galera algunos trucos narrativos sobre la tradición helénica ya preestablecidos por los cánones de su época o por su preferencia para aportar originalidad y erudición a los temas del pasado. La cantera preferida del autor para extraer narraciones es, como se ha señalado muchas veces, el mundo mítico de Homero.

Una de esas anécdotas trata sobre la muerte del héroe Antíloco a manos del etíope Memnón y su relación con la estatua colosal de Memnón en Egipto. Se trata de un ejemplo acotado pero significativo para reflexionar sobre los alcances del relato mítico y la conciencia programática de los escritores sobre sus textos. El relato aparece en tres obras del corpus, Imágenes (Im.), Vida de Apolonio de Tiana (VA) y Heroico (Her.), con variaciones tanto en la forma de presentarlo como en la versión de la historia en sí. El episodio es una de las tantas narraciones mitológicas del Ciclo Troyano citadas por los autores del Imperio, pero lo que distingue a Filóstrato es su trabajo en las variaciones explicativas que llevan de la identificación absoluta entre los dos Memnón a la distinción de dos héroes sin ninguna vinculación entre sí. Es decir, no se trata simplemente de presentar en

\footnotetext{
* Dirección para correspondencia: Instituto de Humanidades y Ciencias Sociales (IHuCSo) del Consejo Nacional de Investigaciones Científicas y Técnicas (CONICET) y la Universidad Nacional del Litoral. El Pozo. Ciudad Universitaria s/n. Santa Fe, Argentina. Correo electrónico: ichialva@gmail.com
} 
diversas obras las variantes de un mito sino de modificar intencionadamente, según el programa de la obra que lo incluye, algunos o todos los elementos que componen el relato ( $\delta$ in $\gamma \eta \mu \alpha)$ según los

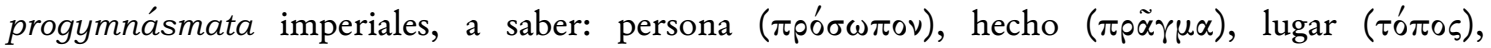

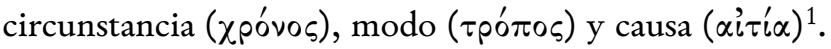

Simultáneamente, tales variantes dan cuenta de un modo de componer relatos en una cultura escrita, con minuciosa consulta de fuentes, reelaboración de materiales antiguos y diversos, manteniendo no obstante el tono de oralidad e improvisación en esa narrativa: un intento de incrementar la sophía griega a partir de su propia tradición clásica pero también de elementos egipcios, helenísticos y romanos. Analizaremos el tratamiento del relato mítico en cada texto y la función creativa de esa re-escritura en la producción de conocimiento de una elite que afirma y preserva el valor de su helenidad en un Imperio cambiante.

\section{Las metamorfosis del relato: Memnón en fuentes iconográficas y textuales}

En la tradición griega existían numerosas referencias al etíope Memnón ${ }^{2}$. Según el relato del Ciclo Troyano, el héroe era hijo de una diosa y un mortal: Aurora y Titono, hermano de Príamo. Durante la guerra, Memnón gobernaba a los etíopes y acudió en ayuda de su tío para defender la ciudad de Troya. Además de una referencia en la Odisea (IV 187), donde Néstor lo señala como el asesino de su hijo Antíloco, sus hazañas en la guerra y su muerte a manos de Aquiles eran narradas en diferentes poemas, como la Pequeña Iliada y la Etiópida ${ }^{3}$. De esta última, Esquilo (o su hijo) tomó material para dos tragedias donde aparecía el héroe y que probablemente integraban una misma trilogía: Memnón y El pesaje de las almas (Psychostasía). Las fuentes narraban su lucimiento en la guerra, con todos los motivos épicos (esplendor de las armas, enfrentamientos heroicos, intervención de las divinidades, etc.) y que, una vez muerto, su madre trasladó el cuerpo a Etiopía donde lo lloraba cada mañana con las gotas del rocío ${ }^{4}$. Paralelamente, en la iconografía clásica, las escenas alusivas al mito repiten esos dos motivos: los enfrentamientos de lucha del héroe o los rituales fúnebres de su cuerpo por su madre. La figura distintiva de Memnón, generalmente de color negro marcando su ascendencia etíope desde la mirada griega, está presente en vasos y ánforas de cerámicas datadas desde el siglo VI hasta finales del IV a.C. y procedentes de diferentes regiones de la Grecia clásica, lo que da cuenta de la extendida difusión del mito ${ }^{5}$.

${ }^{1}$ Reche Martínez, 1991; Kennedy, 2003.

2 Grimal, 1989: 347, Graves, 2007: 216 ss.

${ }^{3}$ Respecto de otros testimonios antiguos sobre Memnón, ver Graves 2007: 216 ss. y Griffith 1998: 213. Acerca de las tragedias de Esquilo, West (2000: 343 ss.) considera que la trilogía completa incluía Memnón, Europa y El pesaje de las almas, de las cuales solamente la primera pertenecería al poeta (a la etapa final de su producción) mientras que las dos siguientes, a su hijo, Euforión. Con respecto al argumento y la estructura posible de las obras, remitimos al mismo artículo.

${ }^{4}$ Una versión diferente se halla en Strab. XIII 11. Allí se ubica la tumba de Memnón en la desembocadura del río Esepo, cercano al Helesponto.

${ }^{5}$ Las piezas conservadas con iconografía alusiva al héroe son numerosas y corresponden, fundamentalmente, al lapso que va de finales del siglo VI hasta finales del s. IV a.C. Del 530 a.C. procede un ánfora de cerámica pintada con figuras negras donde se representa, en un bosque, la escena de duelo donde una blanca Eos llora a Memnón, de piel negra, tendido en el suelo (Musei Vaticani, Italia). Otra ánfora (550-525 a.C.) presenta a un Memnón, de piel negra, asistido por escuderos en la partida hacia Troya (Koninklijke Musea voor Kunst en Geschiedenis, Bruselas). De fecha cercana al 510 a.C., un ánfora de figuras negras muestra a Aquiles y Memnón, escoltados por Tetis y Eos, luchando sobre el cuerpo de Antíloco (Staatliche Antikensammlungen, Munich). Un ánfora de figuras negras (500 a.C.) pintada por Diosphos representa a una Eos alada quien, elevándose en el aire, se lleva en brazos de la batalla el cuerpo inerme de Memnón. En la representación contrasta el color blanco de la piel de la diosa con el color negro del héroe etíope (Metropolitan Museum of Art, Nueva York). También, del mismo período y atribuido al mismo pintor Diosphos, una lékythos de cerámica negra con decoración en colores superpuestos que representa a Eos llevándose a su hijo en brazos (Musée du Louvre, París). Además, se ha conservado un kílix conocido como "piedad de Memnón”, vaso pintado con figuras rojas por el pintor Duris donde se representa el mismo momento, pero con una variante en la imagen: Eos levanta y sostiene en sus brazos el cuerpo sin vida de su hijo, imagen que se asocia a las futuras pinturas de la piedad cristiana. La cerámica procede de la zona de Campania en Italia y fue datada entre 
En época helenística, durante los gobiernos de Ptolomeo I Sóter y Ptolomeo II Filadelfo, el sacerdote egipcio Manetón escribió en griego la célebre Historia de Egipto, donde establecía una cronología que organizaba las diversas dinastías faraónicas desde los tiempos remotos al presente macedónico. Los fragmentos nos han llegado por fuentes indirectas, antiguas y medievales. Se cree que es a partir de esta obra donde se fija la asociación del Memnón etíope del Ciclo Troyano con el faraón egipcio Amenofis III, en un intento de Manetón por establecer algunas simetrías entre las tradiciones míticas griega y egipcia ${ }^{6}$. La procedencia etíope del héroe y la aparente derivación helénica del nombre egipcio de Amenofis o, quizás, la derivación en griego de mennu, que en egipcio significa gran monumento ${ }^{7}$, fue lo que facilitó la asociación del héroe mítico con la estatua de uno de los colosos erigidos durante el reinado del faraón Amenofis III (1387-1348 a.C. aprox.) que representaban al monarca en Lúxor. A partir de época helenística fue conocido como "el coloso de Memnón”. Tal identificación se profundizó después de que un terremoto, en el año 27 a.C., dañara las esculturas y produjera grietas más profundas en una de ellas, la cual generaba sonidos desde el interior de las piedras cuando la iluminaban los rayos del sol. Desde entonces se extendió la leyenda de los sonidos que emitía la estatua al amanecer, como un canto dulce o quejido, reforzando la asociación del héroe muerto con la Aurora (su madre) ${ }^{8}$. Varias fuentes griegas y latinas, a partir del siglo I d.C., atestiguan la fama del coloso Memnón y el prodigio de su lamento: sobre la belleza e importancia de la estatua hablan Estrabón (XVII 1.42) y Plinio (Nat. V 11); sobre los sonidos mágicos de la estatua al amanecer refieren Tácito (Ann. II 61), Juvenal (Sat. XV 5), Pausanias (I 42.3) y Luciano de Samosata (Tox. 27, Philops. 33 8).

El episodio troyano, aderezado entonces por el vínculo con el coloso egipcio, integra el corpus de referencias míticas que combina una serie de rasgos (exótico, mágico y con ascendencia a la antigua Troya) difícil de resistir para un autor de la Segunda Sofística y Filóstrato no es la excepción. El uso de relatos de origen mitológico constituía un recurso propio de la formación retórica (basada en ejercicios progimnasmáticos) cuya función era añadir valor estilístico y conceptual a las narraciones de los pepaideuménoi. La recurrencia de los mismos motivos y referencias míticas en diferentes obras hace pensar no solo en la consulta permanente de las fuentes de las que se extraen sino, incluso, en el trabajo sobre esos motivos que los autores resguardan, posiblemente, en guías de temas o cuadernos para desarrollarlas aportando información o detalles originales, ya sea extraídos de nuevas lecturas o inventadas.

Es conocida, por otra parte, la utilización de cuadernos de anotaciones que funcionaban como ayuda memoria para los pepaideuménoi en la preparación de sus escritos. Lauwers (2012) ha llamado la atención sobre las dificultades del olvido en una cultura de la memoria y la necesidad de preservar la información interesante o valiosa para futuras composiciones por parte de aquellos que participaban de los círculos abocados a las lecturas eruditas. Con relación a esta práctica, son frecuentes los testimonios sobre papeles con listas de temas o citas, hypomnémata y demás

los años 490-80 a.C. (Musée du Louvre, París). Una pieza más tardía, cercana al 300 a.C. y procedente de Turquía, muestra en figuras rojas a Aquiles hiriendo a Memnón. En la parte superior a esas figuras, las divinidades observan a los héroes: Eos con expresión de lamento mira a su hijo herido. Otro motivo frecuente en las pinturas es la escena del pesaje de las almas de Aquiles y Memnón, donde se decide la muerte de este último. Para otros testimonios sobre la figura mítica, remitimos a LIMC (s.v. Memnon, 5287; 5290; 15223; 14666; 201578; 5948; 15208; 202038 (?), 12565; etc.).

${ }^{6}$ En el fragmento que trasmite este pasaje de la Historia de Manetón (según Sexto Julio Africano), Memnón se asocia al octavo rey de la Dinastía XVIII, lo cual, señala el traductor, es un error de la fuente que transmite el texto, ya que la relación debería ser con el noveno rey de la Dinastía, Horus o Amenofis III: 8. Amenofis reinó 31 años. Este es el rey que se considera que fue Memnón y una estatua parlante (Vidal Manzanares, 1993: 47). Griffith (1998), en cambio, considera que Memnón fue asociado al tercer faraón de la dinastía XII, Amenemhat II, quien gobernó unos 35 años en el lapso de 1929-1895 a.C. La referencia en Manetón corresponde al segundo faraón de la dinastía XII, Ammenemes, quien estuvo en el poder 38 años (Vidal Manzanares, 1993: 37).

${ }^{7}$ Herrero Ingelmo, 1994: 196, n. 305.

${ }^{8}$ De las dos esculturas, la situada en posición norte fue la más dañada. Probablemente, los cambios de temperatura entre la noche y la salida del sol y los efectos de los vientos que se filtraban en la piedra generaban sonidos al amanecer. 
anotaciones personales que dan cuenta del recorrido de lecturas e intereses personales de cada autor para retrabajar en sus producciones ${ }^{9}$. Este tipo de investigaciones de lectura permitía, entre otras cosas, advertir contradicciones en los testimonios de los relatos antiguos, explorar las versiones e innovar ese material con nuevos argumentos, temáticas o invenciones. Un procedimiento similar, como trataremos de demostrar, puede advertirse en las variantes del mito de Memnón desarrolladas por el propio Filóstrato.

Otro procedimiento, en estrecha relación con el anterior, es el que analiza Goldhill sobre la forma de difusión de relatos y anécdotas en las obras de los pepaideuménoi. La reescritura de anécdotas biográficas, mitológicas, entre otras, permitía la circulación de un repertorio de temas helénicos ya sea a partir de la memorización y transmisión oral de breves episodios anecdóticos a ser utilizados en performances, como en escritos donde esas mismas anécdotas se insertaban, trabajadas con mayor elaboración, en las narraciones originales de estos autores. Así, oralidad y escritura, convivían y retroalimentaban la transmisión de una cultura. De allí que pueda advertirse en la estructura interna de los autores griegos imperiales, una suerte de compendio de anécdotas y relatos que funcionan a la manera de "manuales" de helenidad:

Handbooks are the archetypal way of packaging a culture under threat, circulating knowledge in restricted units a gesture towards tradition, as that tradition feels increasing need to use such fragmentos to bolster against ruin, a dictionary of cultural literacy. It is a pattern that Cassics as a discipline is all too familiar with. I am suggesting that in Empire culture, parallel to the high level of literacy with its concomitant focus on the book, there is another current whereby information becomes increasingly divided into anecdotal form for oral circulation (2009: 110-111).

Sin duda, poner en contexto esta práctica permite entender cómo el interés en la reescritura minuciosa de relatos míticos, lejos de ser un recurso automatizado y arcaizante -resabio de antiguas lecciones mnemotécnicas de la escuela retórica- revela la sinergia entre la educación libresca basada en las fuentes antiguas, esos mitos novedosamente reescritos y las performances orales como una puesta en común de filiación griega a partir de modelos narrativos específicos.

\section{Memnón en el corpus filostrateo}

\subsection{Los "Memnón" y la figura del doble en Im.}

La serie de $I m$. se inicia con un prólogo donde un sofista celebra la sabiduría de la pintura antigua y decide componer un lógos que sirva de modelo a los jóvenes que deseen interpretarlas

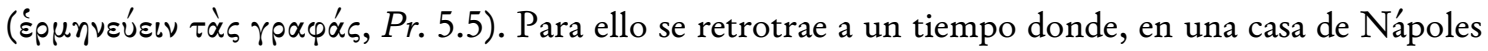

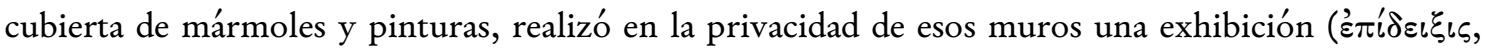
Pr. 5.6), frente al niño de la casa y otros jóvenes, de las descripciones de los cuadros que estaban en la galería. El resultado es una serie de 65 ekphráseis, divididas en dos libros, donde esa epídeixis se transforma en el presente del discurso del sofista que improvisa e interpela al niño en su discurso.

Memnón es el título y tema principal de la graphé 7 del libro I. Allí la ékphrasis representa las honras fúnebres del jefe etíope en Troya. La escena representada, como hemos visto, tenía antecedentes en la iconografía de época clásica, no obstante, en esta versión imperial, a la escena del ritual se suma un elemento propio de los tiempos del sofista.

El texto crea una alternancia entre el tiempo presente de la descripción del cuadro -acompañado por los imperativos de segunda persona al niño-y los tiempos remotos que refieren a los hechos míticos, recuperables por el conocimiento enciclopédico del sofista pero que no están allí representados. No citaremos todo el texto, pero sí unos fragmentos que resultan significativos. La pintura inicia de la siguiente manera:

Es el ejército de Memnón: y aquí se despojan de sus armas y disponen a su jefe para las honras fúnebres, y es que le han atravesado el pecho, según creo, con una lanza. Siempre que encuentro una llanura amplia

\footnotetext{
${ }^{9}$ Es clara la utilización de esta estrategia de escritura tanto en la composición de piezas extensas como en tratados más breves por parte de autores griegos y latinos de la época (Lauwers 2012: 330).
} 
y tiendas y muros en torno a un campamento y una ciudad cercada de muros sé que son estos los etíopes y esta, Troya, y el lamento por Memnón, el hijo de la Aurora ${ }^{10}$.

El inicio de la interpretación del cuadro presenta recursos interesantes: sin duda, la serie de conjunciones que coordinan acciones, primero, y elementos, después, son presentados en serie y de manera estática, no a la manera progresiva del desarrollo de una acción. Se relacionan acciones e imágenes, pero esa vinculación no es una narración encadenada, sino que es el paso de una imagen estática a otra lo que permite armar la secuencia narrativo-descriptiva completa. El estatismo que logra la prosa, como se ha identificado en otras ekphráseis, imita el estatismo de la acción fijada en la pintura. También se incluyen en tiempos históricos las acciones conocidas por el mito que explican la escena representada, de modo que en el presente de la dêิxis se combinan la descripción del cuadro con la narración del mito. Otros recursos ecfrásticos para generar evidencia son los que la crítica ha

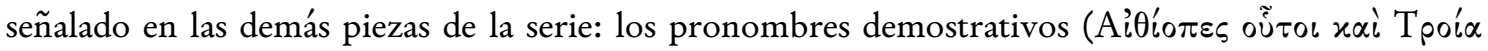
$\tau \alpha \tilde{\tau} \tau \alpha)$, y más adelante, la instancia dialógica entre la primera y segunda persona, el uso de imperativos ligados a verbos de visión y gnómicos $(\sigma x o ́ \pi \varepsilon l \text {, ỡ } \mu \alpha \iota, o ́ p \alpha)^{11}$.

Además de la escena del ritual fúnebre del ejército, la imagen incluye otro motivo también frecuente de la iconografía anterior: la presencia de la diosa y el traslado del cuerpo del hijo.

\begin{abstract}
Y están las divinidades celestes: Eos, llorando por su hijo, vuelve tenue al Sol y pide a la Noche que llegue antes de tiempo y oscurezca el campamento, así por ellos es posible llevarse a su hijo, con la aprobación de Zeus. ¡Y mira! Ya se lo han llevado y está al final de la pintura. ¿Entonces, dónde y en qué parte de la tierra? No es una tumba de Memnón, sino que Memnón, en Etiopía, se ha transformado en piedra negra. Y la figura está sentada y el rostro es el de aquel, creo, y se desliza por la estatua el rayo del Sol. Así parece que el Sol desciende sobre Memnón hasta la boca como si fuera un plectro para emitir desde allí una voz y, con una ilusión de habla (laloûnti sophísmati), consolar (paramytheísthai) a la diosa del Día ${ }^{12}$.
\end{abstract}

Todo el pasaje fluye en una prosa marcada por la oralidad, especialmente los nominativos absolutos que trastocan la sintaxis de las frases. Pero cada rasgo de $\mathrm{Im}$. lejos está de ser improvisado, como pretende hacer creer el sofista. Por el contrario, los detalles (pictóricos, míticos, incluso geográficos) son funcionales, como ha demostrado Webb (2006: 115) a la construcción de la graphé como texto ficcional, e incluso, la impresión de espontaneidad y descuido están cuidadosamente elaborados.

Un ejemplo es, precisamente, el final (espacial y narrativo) de la pintura con la representación del Coloso de Memnón en Etiopía. Si bien no conocemos pinturas de época imperial con este motivo completo, la combinación de las escenas es verosímil y conforma el continuum del relato mítico tal como circulaba en tiempos del sofista. Un rasgo distintivo es la alusión al color: en la escena fúnebre

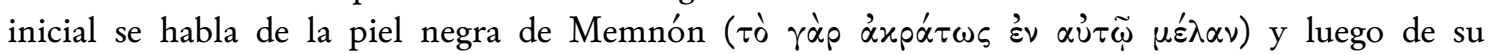

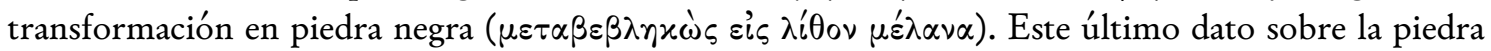
es curioso y parece corresponder a una paleta de colores inventada por el sofista. Los Colosos de Egipto están hechos de piedra cuarcita, como otros templos de la zona de Lúxor, pero esta información empírica no parece importar al sofista quien usa una paleta de colores pertinente a su "paleta" conceptual.

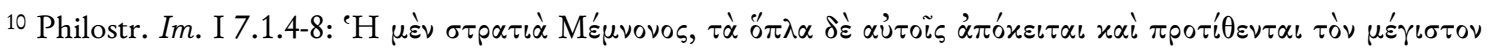

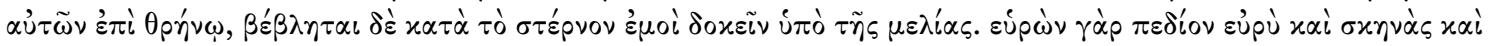

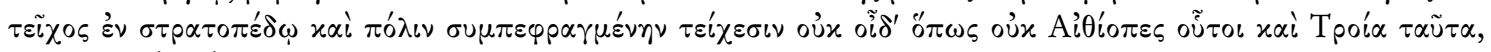

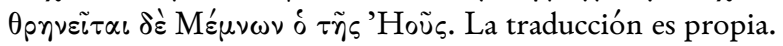

11 Ver los estudios de Manieri (1999), Webb (2006), Chialva (2015), entre muchos otros.

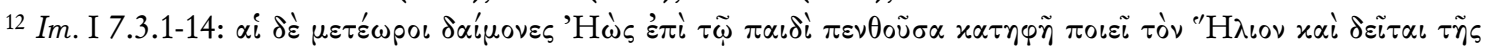

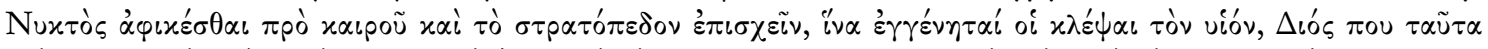

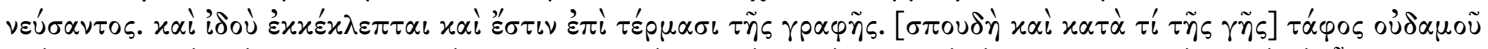

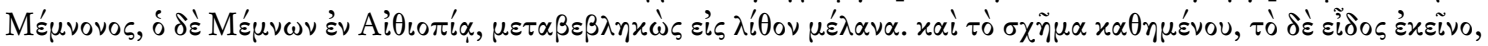

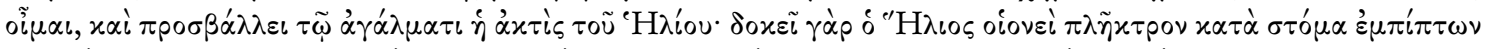

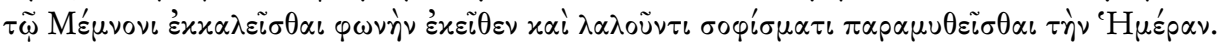


El desplazamiento metonímico del color de la piel a la piedra se conjuga con la apelación a la Noche y a la atmósfera de oscuridad que da lugar a la intervención de la madre. Se juega así en la pintura una serie de contrastes entre Eos - luz - Sol - vida/ Memnón - oscuridad - Noche - muerte que enriquece gráficamente la versión mítica. De allí que, más allá de una hipotética referencia a la iconografía imperial, la identificación de los dos Memnón en la graphé y todo lo que despliegan es funcional al juego especular de conceptos sofísticos propios del autor y que se advierte en el resto de Im.: 1. la relación metonímica entre vida- mito- arte (escultura-pintura) y con ella la disolución de los límites entre realidad e ilusión; 2. la figura del doble mediada por la representación de dos imágenes; 3. el cruce de los niveles de ficción, en este caso, presentar la situación intradiegética como un sofisma (laloûnti sophísmati), desplazando así la ilusión generada por la palabra desde los auditores del sofista a los personajes de la escena ${ }^{13}$; el uso metapoético y especular de términos vinculados a la sophía, como aquí para-mythéomai, que convierte a las figuras del mito en sujetos ellos mismos confortados por la palabra ilusoria de un canto mítico ${ }^{14}$. A esta serie de recursos hay que sumar la relación temporal generada por la imagen entre pasado heroico y presente del sofista. Este lazo temporal, actualizado en la mayor parte de los textos de la Segunda Sofística (Zeitlin, 2001) resulta interesante especialmente en época de Filóstrato ya que no solo el relato de Memnón era, como vimos, conocido y citado frecuentemente por los autores imperiales sino que, incluso, se atribuye a Septimio Severo (esposo de Julia Domna, en cuyo círculo participaba Filóstrato y bajo el amparo del cual compuso algunas de sus obras) un interés especial por la gran estatua y la restauración de las grietas del coloso que terminó callando su canto para siempre ${ }^{15}$. Sin duda, la conexión histórica entre el emperador (de origen africano además) y el coloso, es una explicación posible de la recurrencia de este mito en el corpus, pero también lo es el programa omnipresente en las obras del sofista de construir un helenismo más amplio, más integrador, que sintetice y resignifique elementos foráneos desde la paideía que resulta, a su vez, actual a los nuevos contextos y enriquecida.

Entonces, gracias al desplazamiento geográfico y temporal desde el campo troyano mítico a una Etiopía contemporánea, la coincidencia del héroe y la estatua se logra al vincular todos los elementos de los relatos: la persona (Memnón), hecho (la muerte del héroe / estatua que canta), causa (dolor de la madre), lugar (de Troya a una zona indistinta entre Egipto donde está la estatua y Etiopía de donde procede el héroe), modo (transformación del héroe) y circunstancia (canto al amanecer de la estatua).

La imagen de Memnón tiene su contrapartida en la equivalente ékphrasis 7 del libro II, Antíloco, donde se describen los lamentos ante el cadáver del Nestórida, que ha muerto por defender a su padre, y el dolor de Aquiles mientras medita su venganza sobre Memnón, quien lo mira desafiante al frente del ejército etíope. Si bien la estructura interna de $I m$. ha dado lugar a diferentes

${ }^{13}$ Sobre la preponderancia del término sóphisma en Im. ha tratado Cassin (2008: 332), especialmente en la graphé 23 del Libro I, Narciso, donde se alude al sóphisma del estanque en el que se mira Narciso y el sóphisma del cuadro donde los espectadores miran a Narciso mirarse. Otros conceptos de dimensión metapoética en la serie son apáte (ilusión), mímesis (representación), graphé (pintura-escritura), entre otros. Sobre el cruce de los niveles de ficción ha profundizado Webb (2006) donde detalla los desplazamientos en las instancias de enunciación (sofistalector/sofista-niño/sofista-personajes pintados) y las puestas en abismo de la representación de esas instancias, donde se vuelve indiscernible la dualidad realidad / ficción.

${ }^{14}$ Un recurso similar, donde se funden los niveles de realidad y ficción, estableciendo diversos y sucesivos planos de ilusión artística, ha sido reconocido en Cazadores (I 28), donde los cazadores pintados cobran dinamismo y son seres pseudoreales que ven, a su vez, a su compañero como una figura pintada, así como los niños pseudoreales del discurso del sofista ven a los cazadores pintados y el lector "ve" a los niños y a los cazadores (Cassin, 2008: 332 ).

${ }^{15}$ Incluso se ha utilizado esta referencia histórica como posible indicio para la datación de las tres obras de Filóstrato a las que hacemos referencia, ubicando como terminus ante quem la muerte del emperador Severo en el 211 a.C. El argumento para ello consiste en que, precisamente, las obras de Filóstrato aluden al canto de la estatua, que sería anterior a las refacciones hechas por el emperador. No obstante, como bien señala Decloquement (2019: 51, n. 35), nada indica que el sofista, incluso si compuso sus obras en una fecha posterior, hubiera preferido aludir a un dato histórico preciso en lugar de a una creencia difundida por la tradición literaria, que aportaba al verosímil de su relato. 
conjeturas que justifican la organización aparentemente aleatoria de la serie (ciclos semánticos, temáticos, motivos simétricos, etc.), es interesante el paralelismo completo de Memnón y Antíloco en la galería: desde el punto de vista numérico (ambas corresponden al número 7 de los dos libros), el motivo pictórico (la escena de ritual fúnebre con exposición del cuerpo del héroe) y el relato mítico (ambos personajes completan un episodio narrativo puntual en el marco de la guerra de Troya) ${ }^{16}$.

De modo que, si bien la galería $\mathrm{Im}$. está inmersa (literalmente, ya que es en el segundo nivel ficcional sofista/niños donde la epídeixis sucede) en un contexto de improvisación y registro oral, esa ilusión dialógica está fundada en un trabajo de escritura guiado por una conciencia de artificio ficcional, de estructura y de poética-sofística que subsume y pone a su servicio todos los demás aspectos.

No conocemos exactamente cómo era la performance de esta obra pero, probablemente, la brevedad de las piezas (similar en su forma a las laliaí de las exhibiciones sofísticas) facilitaba la recitación y hacía que pudieran ser declamadas en lecturas públicas una o varias pinturas, según la ocasión. Así, volviendo al planteo de Goldhill, una vez más se observa cómo las obras contemplan esas dos formas de circulación: la lectura completa y minuciosa de la obra escrita (incluso su estudio, memorización e imitación como ejercicio de escritura) pero también la lectura oral, fragmentaria, declamada, que permitía apreciar el relato y asociar rápidamente temas y motivos. Y con esa circulación oral y la diversidad de temas de la galería, el oyente obtenía un breve compendio histórico-mitológico-geográfico-pictórico- de la cultura helénica en el Imperio.

\subsection{Memnón sí, Troya no: fuentes orales y escritas en Apolonio}

Por su parte, en VA la descripción de la estatua de Memnón en Egipto (VI 4) es una de las tantas digresiones del relato biográfico donde la incorporación de detalles exóticos contribuye a la atmósfera de magia y misterio que rodea al personaje principal. Pero, además, la nueva versión dada aquí sobre Memnón es atribuida a la fuente escrita consultada, el manuscrito de Damis que, a su vez, recoge las versiones locales en torno a la estatua. Sobre esta hipotética fuente escrita existe un debate en el cual no profundizaremos aquí pero que, sucintamente, se centra en la autenticidad. El debate se da entre: a) posturas que consideran al autor y su manuscrito una fuente apócrifa inventada por el propio Filóstrato; b) y otras posturas que creen factible la existencia de la fuente, si bien Filóstrato se la apropia, la reescribe y enfatiza aspectos y conceptos propios de su visión personal de la Segunda Sofística que, incluso, pueden encontrarse en otras obras sin la alusión al correspondiente Damis ${ }^{17}$.

Más allá de este interrogante, es precisamente el último punto el que aquí nos interesa: la apropiación de la "posible” versión de Damis sobre Memnón por Filóstrato y su vinculación con los otros testimonios de este personaje en el corpus. Las digresiones y descripciones geográficas abundan en el periplo del personaje por las tierras más diversas que van desde Grecia, Jonia, Italia hasta Egipto, un recorrido propio del imaginario helenístico de la novela, con el acento en su vínculo con los líderes romanos. La visita de Apolonio al templo de Memnón ocurre en su tránsito por los templos del río Nilo, camino al encuentro con los gimnosofistas. Así, el Libro VI se inicia con una extensa descripción de la geografía y los animales que comparten Egipto y Etiopía, mientras la sacra embarcación de Apolonio viaja por el río en esa dirección. Abundan los detalles, las descripciones minuciosas y la información de tipo "etnográfico", muy diferente a la ambigüedad espacial de $I m$. En el parágrafo 4 llegan al templo de Memnón. Dice el sofista:

\footnotetext{
${ }^{16}$ Con relación a este tema, remitimos al interesante trabajo de Braginskaya y Leonov (2006) sobre la composición interna de la serie.

17 Una referencia a los detalles de este debate puede encontrarse en el clásico libro de Anderson (1986: 155 ss.) y en la Introducción de Bernabé Pajares (1992: 25-28).
} 
Sobre Memnón, Damis nos escribe lo siguiente: que fue hijo de la Aurora, pero que no murió en Troya, porque ni siquiera llegó a Troya, sino que murió en Etiopía, tras haber sido rey de los etíopes durante cinco generaciones ${ }^{18}$.

Ya la crítica ha reconocido, en el escrito de Damis, el recurso de citar una fuente anterior, testigo directo de los hechos, para desacreditar versiones de los antiguos mitos, especialmente Homero. En este caso, si bien Memnón (el héroe y la estatua) sigue siendo una sola figura, se corrige la versión transmitida en la Etiópida y la Odisea. Entonces, se mantiene al personaje (Memnón etíope hijo de la Aurora) y la circunstancia (canto al amanecer) pero se modifica el lugar (no fue a Troya, sí reinó en Etiopía), el tiempo (no murió joven en Troya sino anciano en su reino), la causa (gobernó cinco generaciones) y el modo (no hay metamorfosis, solo homenaje con la estatua). Claro que, en esta versión, el valor agregado de la originalidad parece amenguar la coherencia en el relato, ya que las dos versiones quedan sin relación que las justifique. No obstante, la variación es significativa: al mantener la ascendencia con la diosa del Día, pero negar el motivo de la muerte joven del héroe, la escena de la estatua deja de ser un lamento en sí para ser un canto de honra a las fuerzas superiores divinas representadas por la luz, tópico conveniente a la paideía filosófico-religiosa del propio Apolonio.

Una vez citado el mito de Memnón y su culto por los etíopes, se describe el lugar donde se asienta la escultura, según dicen (phasî):

El lugar en el que se alza la estatua, dicen que se parece a una antigua plaza (agorá) como las ágoras que quedan en las ciudades de antigua fundación que presentan ruinas de columnas, vestigios de murallas, asientos, jambas, imágenes de Hermes, destruidos unos por la mano del hombre, otros por el tiempo ${ }^{19}$.

Inmediatamente se advierte la versión helenizada de la presentación del lugar, donde el léxico (repetición de agorá), la alusión a los Hermes (sin ninguna referencia al sincretismo cultural) y la remisión a columnas y demás, hace figurar el complejo con elementos locales de una ciudad griega, matizando todo indicio de cultura extranjera. Tampoco se dan detalles concretos específicos del lugar, como la presencia de un segundo coloso.

Incluso, en la descripción de la estatua sedente ${ }^{20}$, se advierten dos elementos: por un lado, nuevamente, la asimilación en cánones visuales griegos de la iconografía egipcia, asociando los pies unidos del coloso con la referencia a Dédalo; por otro lado, se repite como en la galería de pinturas, la mención al color de la estatua: piedra negra (lithon mélana, Im. I 7.3; lithou mélanos, VA. VI 4.15), enfatizando la identificación del héroe y el coloso. Este dato novedoso, que no se encuentra en otras fuentes griegas alusivas a la estatua, parece ser original del autor, en su insistencia en vincular los dos Memnón, o quizás tomado de su fuente declarada, el hipotético manuscrito de Damis. En la graphé de Im., el negro funciona como metonimia que lleva de la estatua al cuerpo expuesto del etíope en el ejército y, desde allí, a la galería de fuentes griegas (literarias e iconográficas) en el reservorio de la memoria del auditor, que suelen describir con ese adjetivo el color de la piel de Memnón, casi como un epíteto. En el caso de la biografía, la mención del color simula ser una información testimonial del color de las piedras del coloso, referencia que, como hemos dicho, no aparece como tal en otros textos de la época. En todo caso, esa referencia repetida en ambas obras

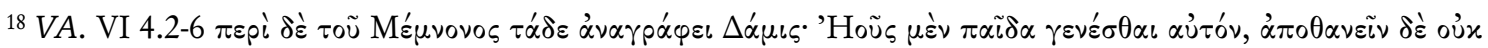

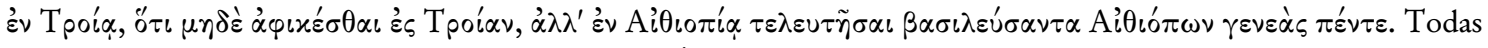
las traducciones de esta obra corresponden a Bernabé Pajares (1992).

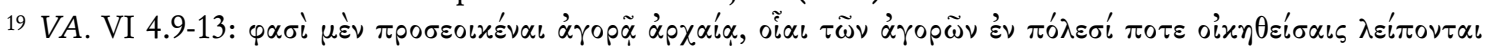

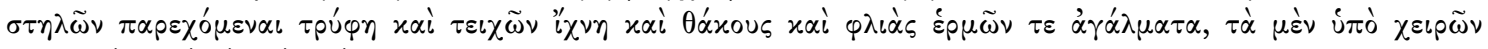

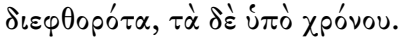

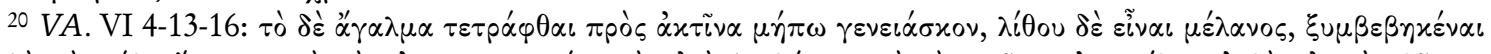

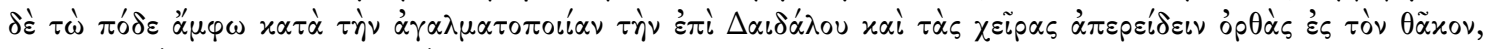

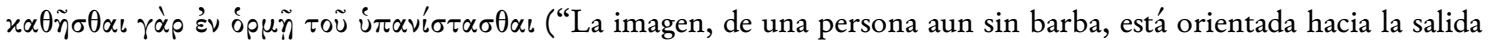
del sol y es de piedra negra; ambos pies están unidos según el estilo de las estatuas de Dédalo. Los brazos se apoyan, rectos, en el asiento, pues está sentado, pero en el momento de ir a levantarse”) (1992: 338). 
del corpus filostrateo, pone en juego un saber inventivo, poético, de tipo libresco, mediante el cual el sofista asocia su propia obra a fuentes griegas anteriores relativas al héroe Memnón, pero también donde activamente incorpora y asimila aspectos culturales extranjeros al gran espectro de la helenidad al trasladar un color del héroe a la estatua.

Al final de la ékphrasis, la "visión" de la estatua pasa del estatismo de la enumeración de rasgos en serie a la narración vívida de la maravilla (thaûma) de la que son testigos Apolonio y su grupo:

Esta actitud, la expresión de sus ojos y la tan celebrada boca, que parece que va a hablar (áidousi), dicen que lo admiraron menos durante un cierto tiempo, pues aún no se les mostró en acción, pero al incidir sobre la estatua los rayos, y esto ocurrió a la salida del sol, no pudieron contener su asombro, pues nada más incidir el rayo sobre la boca produjo un sonido y pareció que sus ojos se ponían brillantes, como los de los que suelen tomar el sol. Dicen que comprendieron entonces por qué parece que está levantándose hacia el sol, como los que se alzan para honrar a un poder superior ${ }^{21}$.

Es interesante cómo el tono mítico del relato da lugar aquí a la espectacularidad del componente sobrenatural y religioso que impregna toda la biografía. Si en el inicio se menciona a Eos, en la descripción abundan las referencias a Helios, el sol, la luz y el culto a un orden divino. Gracias al testimonio, que siempre remite a lo que otros cuentan ( $p$ hasî), los niveles del relato crean sucesivos marcos donde el lector lee-ve que el sofista lee-ve (manuscrito de Damis), que los viajeros miran a la estatua que mira hacia el orden superior. Desde la estatua hasta los receptores del sofista, la vividez del relato produce, con el recurso testimonial, la predisposición a contemplar lo divino en las aventuras de Apolonio en el resto de la narración.

\subsection{Ni héroe etíope, ni Troya, ni canto a la Aurora}

Por último, el Her. (699 1-15) consiste en un diálogo ficcional entre un navegante fenicio y un viñador tracio quien conoce las historias de la guerra de Troya narradas directamente por el alma del héroe Protesilao que visita sus campos. Entre la sucesión de relatos, reaparece el episodio mítico del etíope, pero ahora con una total distinción entre los dos héroes de nombre Memnón. Cuando el viñador narra la muerte de Antíloco en Troya aclara que no lo mató, como muchos cantan en sus versos, un Memnón etíope sino un Memnón troyano. A ese rey de los etíopes, que gobernaba en la misma época de la guerra de Troya, los egipcios y los etíopes le rinden culto cuando la estatua, al amanecer, emite un agradable sonido. A Antíloco, en cambio, lo mató en combate un joven troyano, llamado Memnón, que ganó notoriedad luego de la muerte de Héctor: la diferencia entre uno y otro Memnón desliga al Memnón de Troya de su origen etíope, por lo cual no se hacen alusiones al color de la piel del héroe.

Si bien ya Pausanias había disociado el personaje troyano de la figura representada por el coloso, Famenof (I 42.3) según los egipcios, Filóstrato es la única fuente que conserva el nombre de Memnón para los dos personajes, cada uno con sus componentes del relato particulares. De un relato, se derivan dos. Este detalle sería apenas mencionable como dato curioso si no ofreciera un nuevo indicio acerca de otra forma en la que oralidad y escritura cooperan en la construcción de una sophía helénica. Al justificar la diferencia entre los dos Memnón, el viñador explica que existió, durante la guerra de Troya, un rey etíope Memnón que gobernaba en la misma época en que se dice que el Nilo amontonó la "montaña de arena". La cita (tò psámminon óros, Her. 699 4) recupera literalmente una frase de las Historias de Heródoto (parà tò óros tò psámminon, II 99. 7-8). Esta adhesión, única en las referencias a Memnón en las fuentes conservadas, tiene varias derivaciones. Por un lado, la referencia crea una explicación asociando el rey a aquel que refiere Heródoto, el primer faraón de Egipto, Menes, fundador de Memfis. Claramente, la explicación puede resultar

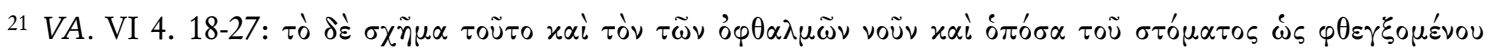

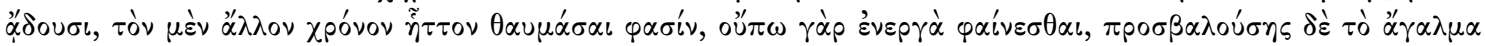

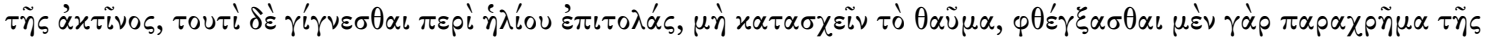

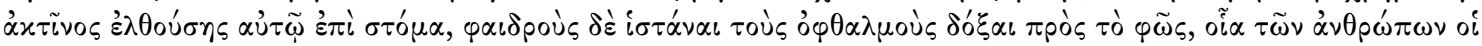

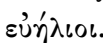


verosímil en un sentido general si se alude a un primer rey de tiempos remotos y se pasa por alto la cronología imposible entre el Menes de Heródoto y el Memnón del viñador. Además, la cita de autoridad velada de la fuente historiográfica permite suponer un vínculo entre ambas figuras y de esta manera generar una explicación libresca para una aparente contradicción del mito. Aquí, la finalidad principal parece ser la de crear versiones del mito alternativas a las homéricas, como sucede a lo largo de toda la obra.

Lo que queda de manifiesto es cómo la variación en la anécdota de Memnón, breve y subsidiaria a otros personajes míticos del mundo homérico, se metamorfosea en base al estudio minucioso de las fuentes clásicas y de la "evidencia" que se pretende crear según el género que la incluye. La misma anécdota permanece pero, simultáneamente, varía y se amplía hasta adquirir una versión propia que corrige otras fuentes del mito ${ }^{22}$.

Tal como hipotetiza Goldhill (2009: 111), si la educación y producción retórica en el Imperio suponía la lectura, estudio erudito, extracción y recomposición de anécdotas mitológicas de fuentes textuales, las performances orales de los sofistas aportaban material renovado, diversificado, para, en un segundo momento, funcionar como fuentes textuales a ser consultadas en otras exposiciones. Desde relatos breves ficcionales, como la ékphrasis de Im. a descripciones documentales como VA o información erudita (posiblemente inventada) de revisión de fuentes antiguas, como en Her., la anécdota mitológica es moldeable según los criterios programáticos del texto que la incorpora. Así, en la rescritura de motivos o anécdotas mitológicas, más que la repetición de relatos ya seleccionados, las obras forman un continuum de revisión, estudio a partir de lecturas, ampliación y corrección de esos motivos en función de una sophía sobre el pasado griego pero, en especial, una sophía propia: las poéticas narrativas de los autores griegos del Imperio.

\section{Bibliografía}

G. Anderson, 1986, Philostratus: Biography and Belles Lettres in the Third Century A.D., London.

A. Bernabé Pajares, 1992, Filóstrato, Vida de Apolonio de Tiana, Madrid.

N. Braginskaya, D. Leonov, 2006, "La composition des Images de Philostrate L'Ancien" en Le défi de l'art. Philostrate, Callistrate et l'image sophistique, M. Costantini, F. Graziani, S. Rolet (eds.), Rennes, pp. 9-29.

I. Chialva, 2015, "Los ríos de Homero: una mirada sofística de la paideia en las Imágenes de Filóstrato", Faventia 37, pp. 71-89.

V. Decloquement, 2019, Commenter, critiquer et réécrire Homère dans l'Heroikos de Philostrate, Thèse de doctorat inédite, Université de Lille.

S. Dubel, 1997, "Ekphrasis et enargeia: la description antique comme parcours", en Dire l'évidence (Philosophie et rhétorique antiques), C. Lévy, L. Pernot (eds.), Paris, pp. 249-264.

J. Elsner, 2009, “A Protean corpus”, en Philostratus, E. Bowie, J. Elsner (eds.), Cambridge, pp. 318.

S. Follet, 2017, Philostrate. Sur les héros, Paris.

S. Goldhill, 2009, "The Anecdote. Exploring the boundaries between oral and literate performance in the Second Sophistic", en Ancient Literacies. The Culture of Reading in Greece, W. A. Johnson, H. N. Parker (eds.), Oxford, pp. 96-113.

R. Graves, 2007, Los mitos griegos II, Madrid.

R. D. Griffith, 1998, “The Origin of Memnon”, ClAnt 17.2, pp. 212-234.

P. Grimal, 1989, Diccionario de mitología griega y romana, Barcelona.

M. C. Herrero Ingelmo, 1994, Pausanias, Descripción de Grecia Libros I y II, Madrid.

C. L. Kayser, 1964, Flavii Philostrati. Opera. Auctiora edidit (ed. minor), Vol. I, Hildesheim. Leipzig.

${ }^{22}$ Cfr. Apollod., Epit. V 3, donde se refiere al Memnón sobrino de Príamo de origen etíope que viaja a Troya. 
C. L. Kayser, 1964, Flavii Philostrati. Opera. Auctiora edidit (ed. minor), Vol. II, Hildesheim.

G. A. Kennedy, 2003, Progymnasmata. Greek Textbooks of Prose Composition and Rhetoric, Atlanta.

J. Lauwers, 2012, "Readings books, talking culture", en Orality, Literacy and Performance in the Ancient World, E. Minchin (ed.), Leiden, Boston, pp. 227-244.

A. Manieri, 1999, “Colori, suoni e profumi nelle Imagines: principi dell' estetica filostratea”, QUCC 63.3, pp. 111-121.

F. Mestre, 1996, Filóstrato. Heroico, Gimnástico, Descripciones de cuadros, Madrid.

F. Mestre, 2007, "Filóstrato y los progymnásmata", en Escuela y literatura en Grecia antigua, J. A. Fernández Delgado, F. Pordomingo, A. Stramaglia (eds.), Cassino, pp. 523-556.

F. Mestre, 2020, "Unité et variété dans la polygraphie de Philostrate", Synthèses $\mathcal{G}^{\circ}$ Hypothèses, 1, «Polygraphies antiques. Variété des formes, unité des œuvres».

M. Reche Martínez, 1991, Teón, Hermógenes, Aftonio. Ejercicios de Retórica, Madrid.

C. Vidal Manzanares, 1993, Manetón, Historia de Egipto, Madrid.

R. Webb, 2010, "Les Images de Philostrate: entre le regard et la constitution du mythe", en Mythe et Fiction, D. Auger, Ch. Delattre (eds.), Paris, pp. 349-365.

R. Web, 2006, "The Imagines as a fictional text: Ekphrasis, apatê and illusion”, en Le défi de l'art. Philostrate, Callistrate et l'image sophistique, M. Costantini, F. Graziani, S. Rolet (eds.), Rennes, pp. 113-136.

M. L. West, 2000, "Iliad and Aethiopis on the Stage: Aeschylus and Son", CQ 50.2, pp. 338-352.

F. Zeitlin, 2001, "Visions and revisions of Homer", en Being Greek under Rome. Cultural Identity, the Second Sophistic and the Developement of Empire, S. Goldhill (ed.), Cambridge, pp. 195-266. 